\title{
TOWARDS SOCIALLY RESPONSIBLE CORPORATE GOVERNANCE WITH AUTHORITIES' INTERVENTIONS
}

\author{
Andreja Primec* \\ Jernej Belak ${ }^{* *}$
}

Received: 10. 11. 2016

Review

Accepted: 22. 5. 2018

UDC 005.35:347.41(4-67EU)

DOI https://doi.org/10.30924/mjcmi/2018.23.1.203

\begin{abstract}
Due to the fact that moral commitments of individuals as well as of corporations were not enough for successful fostering of the socially responsible behaviour of corporations, we are facing the new international and national laws fostering the reporting on non-financial activities of the corporations. We can, therefore, observe how the development of theory on corporate governance, in a relationship with the corporate social responsibility has finally resulted in significant changes in international as well as national legislatives. Therefore, in our paper we examine the legal framework of the EU on corporate social responsibility reporting as well as on non-financial statements of corporations. We analyse the aim,
\end{abstract}

\section{INTRODUCTION}

Due to the requirements for a requisitely holistic approach to governance and management, researchers and practitioners have been working on contemporary solutions; certain efforts have led to the development of integral management and governance.

In this paper, we argue the importance of multi-layer integration of governance the content and the legal effects of this statements under the last amendments from 2014 (Directive 2014/95/EU) and evaluate its contribution to fortifying the role of corporate social responsibility in the corporate governance of EU corporations. The presented paper argues the importance of institutional development in the context of corporate governance and the influence of institutional measures on corporate ethical behaviour and, consequently, on their success implementing the simple aim to protect the interests of all corporations' stakeholders within the framework of corporate functioning.

Keywords: Corporate Governance, Management, CSR, Corporate Governance Statement, non-financial statement

and management with an enterprise and its environment, considering the fundamental aspirations (desires) of the enterprise and, thus, their quantitative as well as qualitative changes (Belak Jer. et al., 2010).

Integration with culture (as well as with science, philosophy, religion, ethics, art, techniques, and technology), credibility, entrepreneurial spirit, and ecology cannot be

\footnotetext{
*Andreja Primec, PhD, University of Maribor, Faculty of Business and Economics, Department of Business Law, Razlagova ulica 14, 20000 Maribor, Slovenia, e-mail: andreja.primec@um.si

** Jernej Belak, PhD, University of Maribor, Faculty of Business and Economics, Department of Strategic Management and Enterprise Policy, Razlagova ulica 14, 20000 Maribor, Slovenia, e-mail: jernej.belak@um.si
} 
limited to a certain section of an enterprise and/or its environment. An enterprise's integration with its broader environment should be implemented in operational, market, and cognitive spaces of the enterprise's functioning and manifested as the enterprise's external capability for objective, time, and spatial alignment of its potential outputs (i.e. services and products) with the needs and expectations of its environment. The integration of the enterprise's internal factors (i.e. material as well as non-material) is manifested as its internal capability and its ability to function efficiently and achieve synergy in all areas. This is the only way an enterprise is able to satisfy the needs and expectations of the environment better than its competitors.

Corporate governance and management on one hand, and social responsibility (SR) on the other, are becoming more and more connected. To prove this statement, it is simply enough to observe the behaviour of corporations. For instance, in Slovenia and in Europe, the number of corporations which "run" for different awards or certificates reflecting social responsible awareness like ISO14001 for environmental management system (ARSO, 2013) is increasing. The other, ISO 26000, social responsibility standard, gained traction and credibility in less than a decade (ISO Organisation, 2018). Corporate governance and management holders currently have to implement corporate values into corporate codes (codes of ethics, codes of conduct/corruption, risk and crisis management, customer and investment relations or other statements of corporate values, responsibility and corporate governance) to cover economic, ethical and environmental dimensions of CSR practices (Caroll, 1991). The ethical dimensions of CSR range from labour practices to social reporting, and environmental from energy efficiency to environmental marketing (Demirbag et al., 2017). This means that corporations not only have the responsibility to stakeholders who have or represent important interests, but also to others outside their business relationships to contribute to the environment and the health, safety and well-being of the whole planet. Throughout the years, socially responsible behaviour has become a kind of "signboard" for corporations hoping for a better reputation on the global market. Despite its controversial use by some recognisable corporations, for example McDonald's, British Petroleum, etc., corporate social responsibility (CSR) remains, or more precisely, gains an important role in corporate governance and management. Since CSR expands a corporation's accountability to wider stakeholders by reporting on their CSR activities (CSRR), it means that boards of directors are responsible for corporate social responsibility reporting. Practical experiences show that formal implementation (moral commitments) is usually not enough, due to the essential purpose of corporations (creating profit). Evidently, the last Volkswagen affaire in 2015 (BBC, 2015), showed that even legal commitments are not enough to prevent criminal acts when huge money is in question. Consequently, in the this paper, we examine the legal framework of the EU on CSRR, with particular focus on the corporate governance statement, established by Directive 2006/46/EC. We analyse the aim, the content and the legal effects of this statement under the last amendments from 2014 (Directive 2014/95/EU) and evaluate its contribution to fortifying the role of CSR in the corporate governance of EU corporations.

Considering the above, we argue that authorities, in a broad sense, have important implications also on corporate governance and on the approach to management in corporations. These changes in national, as well as international legislatives, consequently resulted in requirements for a requisitely holistic approach to governance and management. 
Important efforts have, therefore, led to the development of integral management and governance (Belak Jan. et al, 2014).

In this paper, we argue the importance of the multi-layer integration of governance and management with an enterprise and its environment, considering the fundamental aspirations (desires) of the enterprise and, thus, their quantitative as well as qualitative changes. We base our arguments on both horizontal and vertical integration of an enterprise's governance and management processes, instruments, and institutions into a consistently operating unit. The process, instrumental and institutional integration capacity and integrity of the governance as well as management are initial conditions for the implementation of all other integration factors. Integration with culture (as well as with science, philosophy, religion, ethics, art, techniques, and technology), credibility, entrepreneurial spirit, and ecology cannot be limited to a certain section of an enterprise and/or its environment. An enterprise's integration with its broader environment should be implemented in operational, market, and cognitive spaces of the enterprise's functioning and manifested as the enterprise's external capability for objective, time, and spatial alignment of its potential outputs (i.e. services and products) with the needs and expectations of its environment. The integration of the enterprise's internal factors (i.e. material as well as non-material) is manifested as its internal capability and its ability to function efficiently and achieve synergy in all areas. This is the only way an enterprise is able to satisfy the needs and expectations of the environment better than its competitors.

In our paper, therefore, we introduce the purpose and the importance of the institutional measures of credibility, ethics and social responsibility implementation. The development of the above stated measures implies improved non-financial statements of corporations and, consequently, leads to their success.

\section{ARGUMENT FOR THE NEED OF ETHICAL AND CREDIBLE COMPANY FUNCTIONING}

A company's ethical functioning can be achieved only when the company is entirely committed. Based on the concepts of integral governance and management (Belak et al., 2014; Bleicher, 2004), the above mentioned commitment should take place at political or normative (shareholders), strategic (top management) and tactical/operative (or operational) management levels.

Corporate social responsibility is predicated upon the idea that the functioning of a company does not have only a financial purpose, but a set of three core imperativeseconomic, social and environmental — which guide decisions and activities, and which are equally valid and necessary within the business (Bodny et al., 2012). The idea of a socially responsible corporation, therefore, strongly depends on the corporation's key stakeholders - owners (shareholders) and top management. It refers to the activities of ethics and credibility in a corporation's vision, its policy (defined by Belak 2002 and 2003 as the mission, purposes, and fundamental goals), strategy, and, finally, in the processes and structures necessary for the implementation.

The understanding of governance and management as two important components of the MER model (for the detailed description of the MER model of integral management and governance please see Belak Jan. et al., 2014) is based on a natural hierarchy of the process. While governance is closely related to the ownership of an enterprise and is implementation at the political level, management (in its broader sense) is 
implemented at the lower levels of the hierarchy. As both governance and management are closely mutually related and connected, no special attention is given to the distinction between governance and management processes. The need for the integration of governance and management processes into one complex and requisitely holistic process is also emphasized in several other models of integral management. Processes at different hierarchical levels, as previously described, need to be integrated into one holistic and complex process implemented at three levels: the policy of an enterprise, strategic management, and tactical and operational management level.

Planning, organizing, directing, and controlling are defined as the basic functions of the governance and management process (Belak, 2002; Belak, 2010; Belak, 2014;) in a corporation (the two levels of governance and management process where the official carriers of all activities are owners - at the political level and management of the company, and at the level of strategic management-see Belak, 2002; Belak, 2010; Belak, 2014). They are of great importance in the process of generating the idea of a socially responsible corporation. The idea of an ethical and credible company should be manifested by the company's owners (shareholders) in its policy, which should be based on the vision of an ethical company. Its mission, purposes and fundamental goals should be defined in accordance with its vision of an ethical, credible and, therefore, socially responsible company. According to Bleicher (1994), the vision of such a company must be supported by the company's responsible policy and philosophy, meaning that such company's policy is oriented towards fulfilling the interests of all stakeholders and not only the shareholders' interests since company's policy strongly depends on its owners' values and norms expressed by enterprise culture and therefore company's policy strongly influences a manager's decisions on whether to act ethically or unethically (Rüegg-Stürm, 2002; Belak, Duh 2004; Schweper et al., 1997).

At the strategic management level company's top managers hold the main responsibility for making decisions on strategies and strategic allocation of resources. It is their responsibility to find the most appropriate strategy of becoming an ethical corporation (Belak Jer. et al., 2010). Therefore, it is of great importance to develop an ethics programme by defining the activities and the responsible performers as well as the necessary resources for these activities, which will make strategies action-oriented. This way the company will be able to attain the status of socially responsible company.

In order to successfully realize the planning process at all hierarchical levels, adequate planning instruments should be developed, among which planning methods, in particular, are of great importance (compare with Belak Jan., 2002 and 2003; Belak Jer. et al., 2010), either completely new methods or some of the existing methods could be adopted (proposed by different authors, e.g. Bleicher 2004, David 2008, Hinterhuber 2004, Kajzer, Duh, Belak 2008, Wheelen, Hunger 2009a, 2009b,). The institutional dimension within the proposed concept of a holistic planning model describes the responsibilities of various stakeholders in an enterprise (shareholders and managers) regarding decision-making in the planning process. It also outlines experts and other coworkers who, in accordance with the company's owners and managers, are responsible for business ethics implementation and its ethical functioning (Belak Jer. et al., 2010).

Business ethics is both a broad and a specific topic. As such, it also concerns the wider public, not solely enterprises and 
entrepreneurs. This is clearly demonstrated by recent occurrences of various cases of fraud and functional manipulation of specific enterprises. Such behaviour usually causes dissatisfaction of the parties involved, scandals, and may even lead to an enterprise's bankruptcy. Enterprises are part of our economies, in which they co-create the circumstances of the economic, political, and personal environment. They are increasingly obliged to incorporate ethical frameworks into their functioning.

Key success factors (as well as success itself) are of crucial, strategic importance for all enterprises. Therefore, enterprises should devote a great deal of their attention to these factors. They should identify them and permanently try to improve them. Based on various scientific studies, the following success factors were incorporated into the MER Model of Integral Management and Governance (Belak et. al., 2014): internal and external compatibility of an enterprise, credibility, efficiency, competitiveness, entrepreneurship, synergy, culture, philosophy, ethics and ecology.

The MER model of integral management and governance anticipates (and demands) that the behaviour of all of an enterprise's stakeholders (i.e. owners, management, and others) should be based on credibility - that is, the honest conduct of the entire enterprise in relation to all of its partners, always and in all circumstances. For this reason, credibility should be established and implemented mutually: on the part of the enterprise as an institution in relation to all of its stakeholders individually and on the part of every individual stakeholder (on behalf of the given enterprise) in relation to others.

In this article, we argue for the importance of business ethics and credibility to allow companies to persist as socially responsible and to attain success and maintain their existence over time. Further, we will introduce the informal and formal institutional measures needed for the implementation of the company's ethical and credible functioning and therefore its social responsibility. To successfully implement social responsibility, the correct and appropriate legislation should be developed as the basis for fostering certain social responsibility. In the empirical part of the article, we will present the research in the framework of monitoring the companies' statements on compliance with the Corporate Governance Code in their annual reports. On the basis of the presented research results, the article will present additional legislative (normative) measures that should be adopted and implemented in order to ensure a higher qualitative level of socially responsible, ethical and credible corporate governance in Slovenia. It will also introduce some new institutional measures to improve the understanding of shareholders and top management of Slovenian companies and corporations that the only way to ensure their success and the success of the Slovenian economy is to adopt a stakeholder approach to corporate governance and to act/react in socially responsible ways in the framework of corporate governance and company management process.

Moreover, the paper claims that in order to achieve the socially responsible functioning, a company needs to plan, organize, implement and control the credibility strategy as well as its ethics plan. Furthermore, we present some of the informal and formal measures of business ethics and credibility strategy implementation. 


\section{INFORMAL AND FORMAL MEASURES OF BUSINESS ETHICS AND CREDIBILITY IMPLEMENTATION}

\subsection{Informal measures of business ethics and credibility implementation}

Informal methods and measures play an important role in the socialization process, in which "other employees" play a major role as references for ways of thinking, feeling, perceiving, and evaluating, and as an audience which may be physically present or absent in any interaction, but towards which an actor orientates their conduct" (Casell et al., 1997). Such methods and measures may include a social dimension through which superiors regulate the behaviour of subordinates, or employees regulate the behaviour of their peers through daily interaction in compliance with the enterprise's norms or values. Adam and Moore (2004) argue that informal methods such as the social norms of the enterprise may reflect the enterprise's values and rules of ethics. Enterprise members may be coerced by other members of the group, peers or superiors, to conform to social norms. If not, they risk disapproval, or even rejection. In such a way, the social group exerts pressure on the individual to conform to norms - but only to some degree. Different relationships (e.g. between co-workers, superior vs. team, superiors and subordinates, etc.) may develop in non-formal meetings such as coffee breaks, lunches, sports activities, etc. We can see that informal social norms play a crucial role in forming the social order in an enterprise (Adam, Moore, 2004).

\subsection{Formal measures of business ethics implementation}

According to Adam and Moore (2004), an enterprise can employ diverse mechanisms of control, including documents used during job training that specify the ethical code of conduct, employee performance reviews, and enforcement procedures, etc (for more please see also Adam, Moore, 2004; Sims and Keon, 1999). Such high importance is given to the formal measures of business ethics implementation especially following the research on correlation between formal measures and performance (Morris, 1997; Verschoor, 1998; Wu, 2000; Ye, 2000; Fang, 2006), which reveal that businesses with well-developed formal measures of business ethics implementation record better performance. The businesses that stress ethics have a better image and better public reputation and yield higher long-term interests.

Furthermore, we put special emphasis on the Corporate Governance Code and the Statement of Corporate Governance as key formal measures for companies' implementation of ethical and credible functioning and, consequently, for their success and higher qualitative level of corporate governance.

\subsection{Slovenian corporate governance code}

In the context of legal theory on sources of law, which defers between formal and informal, mandatory (ius cogens) and nonmandatory (ius dispositivum) rules (Kušej, Pavčnik, Perenic, 1998), codes are classified as autonomous (heteronomous) sources, which means that they do not include mandatory rules but rather recommendations. Therefore, in legal theory, the actual question of how to force companies (directors) to respect recommendations of the code is quite complex since many of them do not respect statutory provisions (Bratina, 2017).

The first Corporate Governance Code was adopted just before the accession of Slovenia into the EU in 2004, and it was 
titled the Management code for publicly traded companies (the "Code"). The Code was adopted through the collaboration of the Ljubljana Stock Exchange, the Directors' Association and the Managers' Association. Since then, it has been amended four times in 2005, 2007, 2009 and 2016. The last revision, which has been in use since 1 January 2017, substantially modifies the original text of the Code with an aim of implementing the EU Recommendation. The last amendment of the Code implemented significant change in a frame of Corporate Governance Statement, that is, a new recommendation No. 5.7 of the code. According to the above stated recommendation, the corporations have to provide the external audits revising the compliance of their Corporate Governance Statements with the statuary requirements at least once in a period of three years. Such external audits have to be carried out by the independent institutions with corresponding professional references which have not been involved in any other auditing processes in the company (Bratina, Primec, 2017).

The Code contains 23 leading principles laid down in 112 recommendations, organised in the following chapters: i) Corporate governance framework, ii) Relationship between the company and shareholders, iii) Supervisory board, iv) Management board, v) Independency and loyalty, vi) Audit and internal control, and vii) Transparency of operations.

The Code has three appendices containing definitions and more detailed provisions on supervisory board committees and conflicts of interest. During the last revision of the Code, the signatories prepared a commentary to accompany its leading principles in order to foster a more harmonised interpretation of the Code's recommendations.

The Code applies to all publicly traded companies, especially to those listed on the
Prime and Standard Market of the Ljubljana Stock Exchange for which higher transparency requirements apply. It is expected that the recommendations will be applied to the maximum extent possible. To find information on compliance with the Code easily, the Preamble sets out a requirement that declarations of compliance with the Code should be presented, along with the reasons for deviations from the recommendations, in a declaration of conformity, which is a separate part of the general corporate governance statements. The Code does not, however, set out any additional guidance about how comprehensive and clear the explanations should be. The same obligation to provide a declaration of compliance with the Code is reiterated in the Ljubljana Stock Exchange Inc. Rules for Prime Market and Standard Market issuers. According to these rules, the declaration of compliance with the Code shall be disclosed upon the publication of the annual report, at the latest.

In 2011, the first corporate governance code for state-owned companies was adopted. Due to substantial changes in management of capital assets of the state in the years that followed, it was superseded by two more codes. The last one, the Corporate Governance Code for Companies with Capital Assets of the State, was adopted by Slovenian Sovereign Holding in December 2014 and amended in May 2017. As already suggested by its name, it applies to all companies with state ownership, regardless of their legal form and shareholding level held by the state. This code follows international guidelines for good corporate governance practice, and particularly, the EU guidelines and recommendations, the OECD Guidelines on Corporate Governance of State-Owned Enterprises and the OECD Principles of Corporate Governance. One of the most important goals and intentions of the Code is to raise the quality of corporate governance 
as well as management process in stateowned companies and corporations as well as to realise long-term improvement of the business functioning of those companies and corporations (Corporate Governance Code for Companies with Capital Assets of State, 2017).

As mentioned above, according to the latest amendment to the Slovenian Companies Act of 13 July 2015, all non-public companies whose annual reports are subject to audit have been obliged to provide a corporate governance statement since 1 January 2016. In April 2015, the Ministry of Economic Development and Technology, the Directors' Association, and the Chamber of Commerce and Industry of Slovenia initiated a cooperation for the preparation of a corporate governance code for non-public companies with the main objective of improving the competitiveness of the Slovenian economy. The Corporate Governance Code for Unlisted Companies was adopted in May 2016.

\section{STATEMENT OF CORPORATE GOVERNANCE AS IMPORTANT FORMAL MEASURE OF CORPORATE SOCIAL RESPONSIBILITY IMPLEMENTATION}

\subsection{Role}

A corporate governance statement outlines the information on corporate governance in a company. This data is important for stakeholders dealing with the company (suppliers, creditors, employees, government, banks, investors), allowing them to find out how the company is managed before they commence cooperation. The key role of the

\footnotetext{
1 Point 3 in the Preamble to Directive 2006/43/EC.
}

2 Official Gazette RS, 42/2006,19 April 2006. corporate governance statement is to provide a transparent, efficient and clear governance system inspiring confidence of investors, employees and the general public in the corporate governance system. In this context, it is important to recognise that the overall success of a corporation is no longer measured solely on the basis of it economic results, but also on its responsibility towards society.

\subsection{Implementation and further development}

The corporate governance statement was included in the Directive 2006/46/EC as an integral part of measures aimed at restoring the confidence of the capital market and the general public in companies' annual accounts and reports following serious economic shocks and scandals (Tico, Enron, Parmalat). Enhanced and consistent specific disclosures and publication of information about performance should contribute to improved transparency of the financial management of companies.

Moreover, this Directive sets out the liability of management bodies to draw up and adopt annual reports, including their obligation to approve them by signature. The liability for publishing annual accounts and consolidated accounts as well as annual reports and consolidated annual reports is based on national law. ${ }^{1}$

The requirement to include a corporate governance statement was first implemented in Slovenia in the new Companies Act (ZGD$1^{2}$ ), adopted in 2006 replacing the previous Companies Act (ZGD), adopted in 1993, two years after the Republic of Slovenia proclaimed independence.

That requirement was relatively basic. Companies were obliged to include a 
corporate governance statement in their annual reports stating whether they used any corporate governance code in their business operations, the name of such code, its accessibility to the public and specific provisions of the code not taken into consideration by the company, including a justification (Article 70 of the ZGD-1).

Following the implementation of Directive 2006/46/EC, the above statement was greatly changed two years later with the ZGD-1B amendment ${ }^{3}$. The existing reference of a corporate governance code used by a company was expanded through additional requirements that meant the company should also indicate any code it used voluntarily, any failure to use a code and their reasons for not using one. The statement should contain a description of the main characteristics of the internal control and risk management systems at the company in conjunction with the financial reporting system, as well as the structure and functioning of administrative, management and supervisory bodies and their committees.

Furthermore, the ZGD-1B amendment implemented the requirement of Directive $06 / 46$ from point 8 of Article 1, namely that drawing up and publishing annual reports should be the duty of members of management bodies of a company. To this end, a new article, 60a, was added in the amendment, imposing an obligation on members of the management and supervisory bodies of a company to ensure that annual reports, including the corporate governance statement, are drawn up and published in accordance with the Act, the Slovenian Accounting Standards or the International Financial Reporting Standards. In this respect, they shall act within the scope of their powers, with due care and responsibility as provided for individual forms of companies by the ZGD-1.

As a result of the ZGD-1I amendment in $2015^{4}$, the corporate governance statement was altered once again, although not in terms of its content. The amendment widened the scope for companies that are obliged to include a corporate governance statement in their annual report. Until then, only public companies (companies whose shares are traded on a regulated market) had been obliged to draw up a corporate governance statement, whereas since the implementation of the ZGD-1I amendment, companies whose annual reports are subject to audit (large, medium-sized and dual companies) have also been included.

The ZGD-1I amendment explicitly stipulates that the auditor, when reviewing annual reports, should also review the corporate governance statement by focusing on:

- description of the main characteristics of internal control and risk management systems in the company in relation to the financial reporting process,

- data on significant direct and indirect ownership of the company's shares, in terms of acquiring a qualified holding, as determined by the act governing mergers and acquisitions (full name or corporate name of the holder, number of securities and the proportion they account for in the company's share capital, and nature of ownership),

- data on each holder of securities providing special controlling rights (full name or corporate name of the holder, and nature of ownership),

- data on all restrictions on voting rights,

- an overview of the company's rules on appointment and replacement of members

\footnotetext{
3 Official Gazette RS, 68/2008, 8 July 2008.

4 Official Gazette RS, 55/2015, 24 July 2015.
} 


\section{Journal of Contemporary Management Issues}

of the management or supervisory bodies and amendments to the articles of association;

- authorisations to the management, particularly authorisations to individuals to issue or purchase shares; (Article 57/1 in conjunction with Article 70/5, points 3 and 4).

\subsection{Directive 2014/95/EU and ZGD- $1 \mathrm{I}$}

The corporate governance statement was impacted again by Directive 2014/95/EU, by the requirement concerning the disclosure of non-financial and diversity information by certain large undertakings and groups ("diversity policy"). The main objective of this Directive is to improve social responsibility and, to this end, companies should consider social and environmental issues in managing their business operations and adopting their strategy. The transparency of "non-financial information" may help companies to manage more successfully their non-financial risks and opportunities, thus allowing them to improve their non-financial performance and providing an important source of information for potential investors and civil society when assessing the effects and risks related to the company's performance. Due to the increasing requirements of socially responsible and other investors for non-financial information, more and more companies decide to disclose such information in their annual or other reports. To ensure a level playing field for all businesses, thus allowing comparison between the position and performance of the companies, uniform rules on disclosure of non-financial information should be created at the EU level.

\subsubsection{Board diversity}

Diversity policy refers to the representation in management or supervisory bodies of a company with regard to gender, age or education, and the objectives of that diversity policy, how it has been implemented and the results of the diversity policy in the reporting period. If no diversity policy is applied in a company, the statement shall contain an explanation as to why this is the case.

In the literature, the diversity is described as heterogeneity among board members and has different dimensions ranging from age to nationality, from religious to functional background, from task to relational skills and from political to sexual preference (Van Knippenberg et al, 2004). Several arguments have been put in favour (broad gathering of information, decision creativity and boldness) and against diversity (slowness in decision-making process, conflicts, in-group/outgroup bias) (Hambrick et al, 1996). Some studies, focused on examining the board diversity effect on CSR, have analysed these effects on overall CSR and some have dealt only with specific component of CSR. The most widely used diversity characteristic in the literature are board independence, age diversity and directors' occupational background. The results mostly show a positive relationship between board independence and CSR. Independent board members are more concerned with the ethical aspects of the corporation (Ibrahim et al., 2003) and are more interested in compliance with regulations and responsible behaviour (Zahra, Stanton, 1988). Studies, researching the relation between age diversity among board members and CSR establish that achieving synergy between the experience of older and the energy of younger managers is important in the decision-making process. Older managers are more concerned about welfare of the society, while the younger ones are more sensitive to environmental and ethical issues (Hafsi, Turgot, 2013).

The requirement to describe the diversity policy was transposed to the ZGD-1 by means of the ZGD-1I amendment, with the 
obligation applying to all companies liable to drawing up an annual report. For the purpose of compliance with Directive 2014/95/ EU, the "description of diversity policy" has become part of the corporate governance statement, which commits only the companies subject to audit. Moreover, Directive 2014/95/EU lays down the obligation to disclose important information in the form of a statement within the annual report of a company.

Even before the adoption of Directive 2014/95/EU, the issue of board diversity with regard to gender was addressed in legal regulations in the form of 'female quotas' in some European countries. The first country to adopt the law requiring a minimum of 40 per cent representation of both sexes in the boards of listed companies and employing more than 500 workers was Norway. It was followed by Spain, Sweden, France and Italy (Rao K., Tilt C, 2016), adopting either legislative or voluntary initiatives to establish female representation in boards. It seems that gender diversity is to be an issue of interest not only in the diversity literature but also in politics (Kang et al. 2007). Even more, it has become an ongoing global issue (Rao K., Tilt C, 2016). Most of the literature on gender diversity found out the significant differences in values, perceptions and beliefs between men and women. Some characteristics (being assertive, aggressive, independent, self-confident, competitive) are usually recognized in men, whereas communal characteristics, such as being helpful, affectionate, interpersonally sensitive, nurturing, and gentle are identified in woman (Eagly et al., 2003). Women usually hold positions in "soft" managerial areas, such as human resources, CSR or marketing (Zelechowski and Bilimoria, 2006).

According to the survey conducted by the Slovenian Directors' Association (ZNS), the average representation of women in decision-making bodies in Slovenian public limited companies was higher $(17 \%)$ in 2010 than the EU average (10\%) (ZNS, 2011). The Proposal for a Directive of the European Parliament and of the Council on improving the gender balance among nonexecutive directors of companies listed on stock exchanges and related measures from 2012 , set the goal of reaching $40 \%$ of female representation in decision-making bodies by 2020. As the European Parliament states in its resolution on progress in achieving equality between women and men in the European Union from 2015, this aim, unfortunately, will not be achieved, with the exception of France, where a compulsory legislative quota has been introduced.

\subsubsection{Requirement on non-financial information disclosure}

The second requirement, i.e. the requirement on non-financial information disclosure was transposed into the Slovenian legal order by the ZGD-1J draft amendment. According to the ZGD-1J draft amendment, drawn up by the Ministry of Economic Development and Technology of the Republic of Slovenia in 2016, only large undertakings that are public-interest entities employing more than 500 people on average, shall prepare a nonfinancial statement. Moreover, companies obliged to draw up a consolidated annual report and employing on average more than 500 people on a consolidated level, shall also be obliged to prepare a non-financial statement in compliance with the draft. In accordance with the new Article, 70b, of the ZGD-1, these companies shall include a non-financial statement in their management report. This statement contains information to the extent necessary for an understanding of the undertaking's development, performance, position and impact of its activity, relating to, as a minimum requirement, 
environmental, social and employee matters, respect for human rights, anti-corruption and bribery matters. The above indicated information refers to the previous period of operations. Directive 2014/95/EU explicitly stipulates that small and medium-sized undertakings shall be exempt from this obligation which is taken into consideration in the proposed ZGD-1J amendment. In light of the foregoing criteria and publicly available data of the Agency of the Republic of Slovenia for Public Legal Records and Related Services, fewer than 50 undertakings established in the territory of the Republic of Slovenia shall be obliged to prepare a non-financial statement (Draft ZGD-1J amendment, p. 7).

Disclosure of non-financial information represents a significant challenge to management and supervisory bodies. Corporate managers and directors are often exposed to conflicts of interest between responsibility for ensuring maximized firm value (as a legal obligation to shareholder) and specific duties to society. For that reason, their decisions require compliance with regulation/ law and cooperation with the underlying spirit of regulation/law (Rose J. M., 2006).

Directives 2014/95/EU and 2013/34/EU provide that the statutory auditor or audit firm shall express an opinion regarding the information in the prepared corporate governance statement (according to the ZGD-1, these are points 3 and 4, paragraph five of Article 70 of the ZGD-1, already described in detail), while regarding the non-financial statement and other data forming part of the corporate governance statement, the statutory auditor or audit firm should only check that the nonfinancial statement or other data has been provided by the company - without examining the substance. The above mentioned auditor's obligation to check such statements in the management report increases the responsibility of the management team to draw up these statements, as it knows in advance that they will be subject to review, at least to a minimum extent (Bratina, 2016).

The ZGD-1J proposal integrated this requirement into Article 57, stipulating the auditor's obligations when auditing annual reports. Now, however, the limits of the auditor's authorisations or duties are specified in more detail. As a result, auditors will now have to audit the financial report and review the management report to the extent necessary to check whether its content is in compliance with other elements of the annual report. Moreover, auditors will also have to verify whether the management report contains a non-financial statement and a corporate governance statement and to check them for completeness. When reviewing the content, however, auditors will focus on the review of data from points 3 and 4, paragraph five of Article 70 of this Act.

\subsection{Observations}

The corporate governance statement is a legal concept introduced by Directive 2006/46/EC. It has been chosen as an example of institutional measures that will contribute to the implementation of corporate social responsibility and its integration in the day-to-day business agenda of corporations. Initially, the statement was conceived as an attempt to influence management and supervisory bodies in terms of raising their awareness of the importance of management and governance of their companies even outside the narrow circle of shareholders, namely, to have a significant influence on capital markets or the wider social environment through their company management. Gradually, legal requirements started to expand in terms of content. As a result, the original informative nature of the statement turned into a complex data set that any company's management should collect, integrate into their management report and publish in accordance with 
the requirements that apply to the publication of annual reports. The management bears full responsibility for the credibility of these reports. Moreover, an auditor is involved and responsible for the review of this statement (with the adoption of the ZGD-1B amendment as a consequence of the implementation of Directive 2006/46/EC).

As the content of the statement expands, so does the responsibility of the management and supervisory bodies obliged to report thereon. Moreover, reporting is becoming more comprehensive. Other than the responsibility imposed on the management and supervisory bodies by the general rules of national corporate law, gradual extension of the work of the auditor in having to pay an increasing attention to the corporate governance statement in the review of the annual report, constitutes an additional responsibility. Therefore, for the management and supervisory bodies, the extension of an auditor's competence is just one more reason to perform their duties with responsibility and due care.

\section{CONCLUSIONS}

It can be concluded that, through the corporate governance statement (and nonfinancial statement), the legislator constantly increases its pressure on the owners as well as management and supervisory bodies of the companies regarding their awareness of ethical values (environmental, social, etc.). By the last amendments of EU (Article 1 of Directive 2014/95/EU) and consequently Slovenian legislation, the corporations have to report more preciously on economic, social, environmental issues. The members of management and supervisory board become legally responsible for credibility of such data (60a Article of ZGD-1).
Moreover, the statement has educational effects. Since drawing up a Corporate Governance Statement is becoming annual practice, the management and supervisory bodies are repeatedly being confronted with these issues and must make more ethical decisions. Simply put, through their nonfinancial statements, the corporations have to show their socially responsible behaviour through the stated and defined projects, realised activities and plans for the future years, which will improve their non-financial (read: social responsible, ethical, credible) behaviour. Consequently, the owners' rights, represented by boards' members, are mediated by those of other stakeholders and in such circumstances firms and corporations are more likely to be socially responsible (Jackson, Apostolakau, 2010). Institutional theorists assert that in the contexts with stronger rights bestowed to other stakeholders and interest groups, institutional actors such as nongovernmental organizations can be particularly effective and successful in monitoring corporate behaviour, influencing the policy-making process, and thus exerting pressure on firms to be more socially responsible (Campbell, 2006). As a result, the corporate social responsibility is increasing.

Regarding the review of the corporate governance statement, the conclusion is that imposing control over reporting is certainly a correct decision and a necessary measure, but auditors as experts in accounting and financial matters usually lack the necessary skills to be able to assess those parts of the corporate governance statement being outside the area of their work (social and environmental issues, respect for fundamental human rights, etc.). In order to make these aspects of social responsibility in the field of corporate governance and management even more explicit, it would be reasonable to consider the option of engaging an independent expert in non-financial corporate governance 
matters to have control over reporting in the future.

The important guideline or solution regarding the quality of corporate governance as well as management and, consequently, regarding its influence on the success of corporations, is a consistent stakeholder approach in doing business. In order for a company to be successful in the long run, it is of great importance to consider the interests of all stakeholders, even the least powerful ones. Of course, these interests would have to be negotiated and accepted by all stakeholders, especially the key stakeholders - the owners and managers. Furthermore, institutionally speaking, there is a need for companies to report their nonfinancial information in their corporate governance statements and non-financial statements, where the activities and the companies' goals, considering the interests of all other stakeholders, besides

\section{REFERENCES}

1. Act Amending the Companies Act (ZGD-1B), OJ RS 68/2008, 8. 7. 2008.

2. Act Amending the Companies Act (ZGD-1I), OJ RS 55/2015, 24. 7. 2015.

3. Adam A. M., Moore D. R. (2004). The Methods Used to Implement an Ethical Code of Conduct and Employee Attitudes. Journal of Business Ethics, 54(3), 225-244.

4. ARSO (2013). Kazalci okolja Slovenije. http://kazalci.arso.gov.si/print?ind $\mathrm{id}=525 \&$ lang_id=302 (17.5.2018).

5. BBC (2015). BBC News. http://www. bbc.com/news/business-34324772 (17. 5. 2018.)

6. Bratina B. (2016). Novosti v korporativnem upravljanju. Zbornik referatov XXXI. Posvetovanja društva računovodij, finančnikov in revizorjev Maribor, p. $25-37$. the owners' interests, would have to be explained in detail. This way, the interests of all company stakeholders would be considered, or at least represented, with the key stakeholders - especially the company's owners and managers. In our opinion, the standardization of corporate non-financial reporting will be the basis for the authorities' next step - reinforcement of the monitoring of the quality of such reporting. The last mentioned regulation is also the newest regulation in this context - the first non-financial reporting will be done by European (and therefore also Slovene) corporations within annual reporting in 2018 for the business year of 2017. Our future research activities will, therefore, be focused on and interested in the quality of non-financial statements of the EU corporations and the alignment of non-financial statements with their corporate governance statements and statements about their policies of governance.

7. Bratina B. (2017). Kodeks upravljanja in revizorjeva odgovornost. SIRIUS 4/17, 5-22.

8. Bratina B, Primec A. (2017). Izdelava poslovnih poročil, izjav o upravljanju ter izjav o nefinančnih informacijah $\mathrm{v}$ konsolidiranih letnih poročilih in letnih poročilih posameznih gospodarskih družb. Podjetje in delo, 6-7/43, 977-988.

9. Belak, Jan., Belak, Jer., Duh, M. (2014). Integral management and govern-ance: Basic features of MER model. Saarbrücken: LAP Lambert Academic Publishing.

10. Belak Jan. (2002). Politika podjetja in strateški management (Enterprise policy and Strategic Management). Maribor: Mer Publishing House.

11. Belak Jan. et al. (2003). Integralni management in razvoj podjetja (Integral Management and Enterprise 
Development). Maribor: Mer Publishing House.

12. Belak Jan., Duh M. (2004). MER Model of Integral Management: Concept and Basic Features. In: Proceedings, Jubilee Conference. Budapest.

13. Belak, Jer., Duh, M., Mulej, M.,Štrukelj, T. (2010). Requisitely holistic ethics planning as pre-condition for enterprise ethical behaviour. Kybernetes 1(39), 19-36.

14. Bleicher, K. (1994). Normatives management: Politik, verfassung und philosophie des unternehmens. Frankfurt: Campus Verlag.

15. Bleicher K. (2004). Das Konzept des Integriertes Management: Visionen, Missionen, Programme. Frankfurt: Campus Verlag.

16. Campbell, J. L.(2007). Why would corporations behave in socially responsible ways? An institutional theory of corporate social responsibility. Academy of Management Review, 32, 946-967.

17. Caroll, A. B. (1991). The pyramid of corporate social responsibility: Toward the moral management of organizational stakeholders. Business Horizons, 43(4), 39-48.

18. Casell C., Johnson P., Smith K. (1997).: Opening the Black Box: Corporate Codes of Ethics in Their Organizational Context. Journal of Business Ethics, 17.

19. Corporate Governance Code for Companies with Capital Assets of State. (2017), http://www.zdruzenje-ns.si/uploads/KODEKS_SDH_-_maj_2017.pdf (9. 5. 2018).

20. Companies Act (ZGD-1), OJ RS 42/2006, 19. 4. 2006.

21. David, Fred R. (2008). Strategic Management: Concepts and Cases: International Version. 12th Edition.
New Jersey: Pearson Education, Inc., Upper Saddle River.

22. Demirbarg. M. et al. (2017). Varieties of CSR: Institutions and Socially Responsible Behaviour. International Business Review 26(6), 1064-1074.

23. Directive 2006/46/EC of the European Parliament and of the Council of 14 June 2006 amending Council Directives $78 / 660 / \mathrm{EEC}$ on the annual accounts of certain types of companies, 83/349/EEC on consolidated accounts, 86/635/EEC on the annual accounts and consolidated accounts of banks and other financial institutions and 91/674/EEC on the annual accounts and consolidated accounts of insurance undertakings (Text with EEA relevance), OJ L 224, 16.8.2006, 1-7.

24. Directive 2014/95/EU of the European Parliament and of the Council of 22 October 2014 amending Directive 2013/34/EU as regards disclosure of non-financial and diversity information by certain large undertakings and groups Text with EEA relevance, OJ L 330, 15.11.2014, 1 - 9

25. Fang M. L. (2006). Evaluating Ethical Decision-Making of Individual Employees in Organizations - An Integration Framework. Journal of American Academy of Business, 8(2), 105-112.

26. Hafsi, T., Turgut, G. (2013). Boardroom Diversity and its Effect on Social Performance: Conceptualization and Empirical Evidence. Journal of Business Ethics, 112(2), 463-479.

27. Hinterhuber, Hans, H. (2004): Strategische Unternehmungsführung. 7. grundlegend neu bearbeitete Auflage, Berlin - New York: Band I und Band II.

28. Kušej G., Pavčnik M., Perenič A. (1998). Uvod v pravoznanstvo. Ljubljana: ČZ Uradni list RS. 
29. Proposal for an Act Amending Companies Act (ZGD-1J http://www. mgrt.gov.si/fileadmin/mgrt.gov.si/pageuploads/predpisi/ZGD-1J_gradivo.doc (23. 11. 2016).

30. Proposal for a Directive of the european parliament and of the coun-cil on improving the gender bal-ance among non-executive directors of companies listed on stock ex-changes and related measures http://eurlex.europa.eu/legal-content/SL/

$\mathrm{TXT} /$ ?uri=CELEX\%3A52012PC0614 (28. 11. 2016).

31. Hambrick D. C., Cho T. S., Chen, M. J. (1996) The Influence of Top Management Team Heterogeneity on Firms ' Competitive Moves, Administrative Science Quarterly, 41 (4), 659 - 684.

32. Ibrahim, N.A., Howard, D.P. \& Angelidis, J.P. (2003). Board Members in the Service Industry: An Empirical Examination of the Relationship Between Corporate Social Responsibility Orientation and Directorial Type. Journal of Business Ethics, 47(4), 393 - 401.

33. ISO Organisation (2018). https:// www.iso.org/news/ref2204.html (17. 5. 2018).

34. Jackson, G., Apostolakau, A. (2010). Corporate social responsibility in western Europe: an institutional mirror or substitute? Journal of Business Ethics, 9, 371-394.

35. Kajzer S̆., Duh M., Belak J. (2008). Integral Management: concept and basic features of the MER Model. Zeitschrift für KMU und Mittelbetriebe, Duncker \& Humblot, Berlin.

36. Kang, H., Cheng, M., Gray, S. J. (2007). Corporate Governance and
Board Composition: diversity and independence of Australian boards. Corporate Governance An International Review, 15(2), $194-207$.

37. Morris H. M. et al. (2002). The Ethical Context of Entrepreneurship: Proposing and Testing a Developmental Framework. Journal of Business Ethics, 40(4), 331-361.

38. Morris S. A. (1997). Internal effects of stakeholder management devices. Journal of Business Ethics, 16(4), 413-424.

39. Rao K., Tilt C. (2016). Board Composition and Corporate Social Responsibility: The Role of Diversity, Gender, Strategy and Decision Making. Journal of Business Ethics, 138(2), 327-347.

40. Rose, J. M. (2007). Corporate Directors and Social Responsibility: Ethics versus Shareholder Value. Journal of Business Ethics, 73(3), 319-331.

41. Resolucija Evropskega parlamenta z dne 10. marca 2015 o napredku pri doseganju enakosti med ženskami in moškimi v Evropski uniji leta 2013 (2014/2217(INI)), http://www.casnik.si/wp-content/uploads/2015/03/ Resolucija-Evropskega-parlamentao-enakosti-spolov-2013-Tarabella.pdf (28. 11. 2016)

42. Rüeg-Stürm J. (2002). Das Neue St. Galler Management-Modell. Grundkategorien einer integrierte Managementlehre. Bern: Haupt.

43. Schwepker, Jr., C. H., Ferrel O. C., \& Ingram, T. N. (1997). The influence of ethical climate and ethical conflict on role stress in the sales force. Journal of the Academy of Marketing Science 25(2), 99-108.

44. Sims R. L., Keon T. L. (1999). Determinants of Ethical Decision 
Making: The Relationship of the Perceived Organizational Environment. Journal of Business Ethics, 19(4), 393-401.

45. Van Knippenberg, D, De Dreu, C. K. W., Homan, A. C. (2004). Work group diversity and group peromance: An integrative model and research agenda. Journal of Applied Psychology, 61, 1008-1022.

46. Verschoor C. C. (1998). A study of the link between corporation's financial performance and its commitment of ethics. Journal of Business Ethics, 17(13), 1509-1516.

47. Wheelen, T. L., Hunger, J. D. (2009a): Strategic Management and Business Policy: Achieving Sustainability. 12th Edition. Upper Saddle River (NJ): Pearson Education.

48. Wheelen, T. L., Hunger, J. D. (2009b): Concepts in Strategic Management and Business Policy. 12th Edition. Upper Saddle River (NJ): Pearson Education.
49. Wu C. F. (2000). The relationship among ethical decision-making by individual, corporate business ethics, and organi-zational performance: Comparison of outstanding SMEs, SMEs, and large enterprises. Taiwan, 11(1), 231-261.

50. Ye K. D.(2000). The impact of information asymmetry situation on R\&D's work ethics perception. Asia Pacific Management Review, 5(2).

51. Zahra, S. A., Stanaton, W. W. (1988). Boards of Directors and Corporate Financial Performance: A Review and Integrative Model. Journal of Management, 15(2), 291-334.

52. Združenje nadzornikov Slovenije (ZNS) (2011): Rezultati raziskave o zastopanosti žensk $v$ organih vodenja in nadzora javnih delniških družb v Sloveniji.

53. Zelechowski, S., Bilimoria, D. (2006). Characteristics of CEOs and boards with women inside directors. Corporate Board: Role, Duties and Composition, 2(2),14-21.

\section{PREMA DRUŠTVENO ODGOVORNOM KORPORATIVNOM UPRAVLJANJA UZ INTERVENCIJU VLASTI}

\section{SAŽETAK}

$S$ obzirom da moralna posvećenost pojedinaca, kao ni korporacija, nisu bile dovoljne za uspješno poticanje društveno odgovornog ponašanja korporacija, u suvremenom se okruženju javljanju novi nacionalni i međunarodni zakoni, koji zahtijevaju izvještavanje o nefinancijskim aktivnostima korporacijama. Stoga se može pratiti kako je razvoj teorije korporativnog upravljanja, povezan s teorijom korporativne društvene odgovornosti, konačno doveo do značajnih promjena nacionalnih $i$ međunarodne pravne regulative. Stoga se, u ovom radu, analiziraju pravni okvir
EU-a u području izvještavanja o korporativnoj društvenoj odgovornosti, kao i o izvještavanju o nefinancijskim aktivnostima korporacija. Utvrđuju se ciljevi, sadržaj i pravni učinci pravnog okvira, u skladu s posljednjim nadopunama iz 2014. godine (Direktiva 2014/95/EU) te vrednuje njegov doprinos pojačavanju uloge korporativne društvene odgovornosti u korporativnom upravljanju u EU-u. U radu se ustvrđuje značaj institucionalnog razvoja u kontekstu korporativnog upravljanja i djelovanja institucionalnih mjera na etičko korporativno ponašanje, a samim tim, i na njegovu uspješnost u postizanju zaštite interesa svih dionika u funkcioniranju korporacija. 
